\title{
Prolaps mitrální chlopně způsobený infekční endokarditidou
}

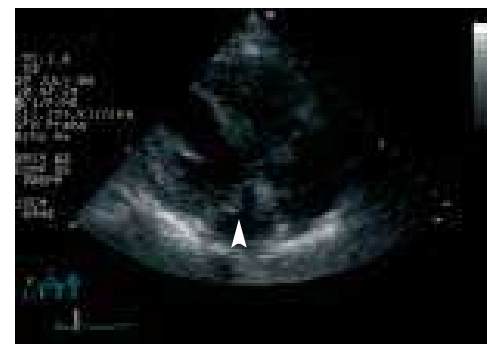

Obr. 1 Transtorakální echokardiografie, parasternální dlouhá osa; měnič je sklonĕn posteromediálně; šipkou je označeno systolické vyklenutí zadního cípu mitráln chlopně do levé síně

Klinický obraz infekční endokarditidy (IE) mưže být pestrý vzhledem $\mathrm{k}$ celé řadě možných komplikací. Podle patogeneze lze komplikace IE rozdělit na: 1. embolické (např. ischemická cévní mozková přihoda, akutní infarkt myokardu), 2. způsobené lokálnim šířením infekce (destrukce chlopně paravalvulární absces), 3. metastatické (osteomyelitida obratle, mozkový absces) a 4. imunologicky podminěné (glomerulonefritida).

V naši kasuistice je popsána vzácná komplikace IE, podmíněná lokálním šířením infekce, $v$ podobě aneuryzmatického vyklenutí cípu chlopně imitujicího prolaps. Šedesátičtyřletý muž byl prrijat pro obstrukční ikterus při cholelitiáze a stenóze distálního choledochu. Stav byl řešen cholecystektomiî a choledocho-jejunoanastomózou. Pooperační průběh byl komplikován akutni pankreatitidou se vznikem objemné pankreatické pseudocysty. Za 5 měsíců od operace byl nemocný rehospitalizován pro váhový úbytek o $15 \mathrm{~kg}$, únavu a febrility, které byly nejprve intermitentni, $\mathrm{v}$ poslednich 2 týdnech pak již trvalé se zimnicí a třesavkou. V laboratorním obraze byl nález periferní pancytopenie, zvýšení CRP, D-dimerů a pozitivní hemokultury s nálezem Enterococcus faecalis. Při vyšetřeni transtorakálni echokardiografií byl zachycen prolaps zadního cípu mitrální chlopně při posteromediální komisuře (obrázek 1) s významnou doprovodnou mitrální regurgitací s charakteristicky asymetrickým regurgitačním jetem, směřujícím $\mathrm{k}$ posterolaterální stěně levé sině. Jícnová echokardiografie potvrdila

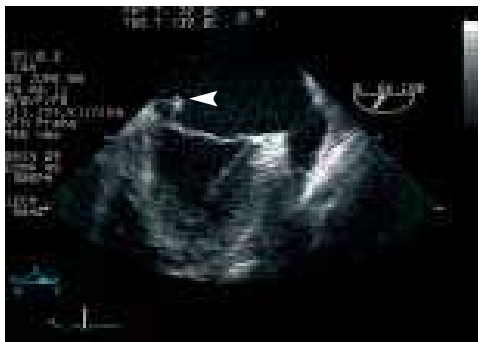

Obr. 2 Transezofageální echokardiografie (TEE), dvoudutinová projekce se zobrazením ouška levé síně; prolabující zadní cíp mitrální chlopně se ztenčením mediáln části stěny vyklenutí (označeno šipkou)

nález lokalizovaného vyklenutí zadního cípu v oblasti scalopu P3, s ložiskovým ztluštěnim, možnou drobnou vegetací staršîho data, ale rovněž i se ztenčením mediální stěny daného vyklenutí. Nebyly přitomny typické známky myxoidní degenerace cípů chlopně, které bývají u primárního prolapsu (obrázek 2). Dopplerovsky byla potvrzena i významná mitrální regurgitace (obrázek 3). Septický stav byl zvládnut dlouhodobou cílenou antibiotickou léčbou.

Vzhledem k echokardiografickým známkám objemového přetížení levé komory, a posléze i klinickým projevưm počínajícího levostranného srdečního selhávání, byl nemocný indikován ke kardiochirurgickému výkonu. Až při operaci se zcela objasnil rozsah a charakter postiženi mitrální chlopně (obrázek 4). Bylo nalezeno aneuryzmatické vyklenutí zadního cípu mitrální chlopně s perforací, se dvěma vedle sebe lokalizovanými otvory. Byla provedena resekce postižené části chlopně, implantace anuloplastického prstence a jednoduchého koronárního bypassu na ramus interventricularis anterior levé věnčité tepny

pro předoperačně zjištěnou významnou stenózu. Pooperační průběh byl nekomplikovaný, mitrální chlopeň se stala plně kompetentní. Záchovná operace na mitrální chlopni byla pro nemocného výhodná i vzhledem $\mathrm{k}$ reálnému riziku exacerbace chronické pankreatitidy a možné budoucí nutnost intervence v oblasti žlučových

a pankreatických vývodných cest. Prolaps mitrální chlopně (PMCH) se dělí na primární a sekundární. Primárni PMCH se vyskytuje jako familiární, nefamiliární a spojený s dědičnými

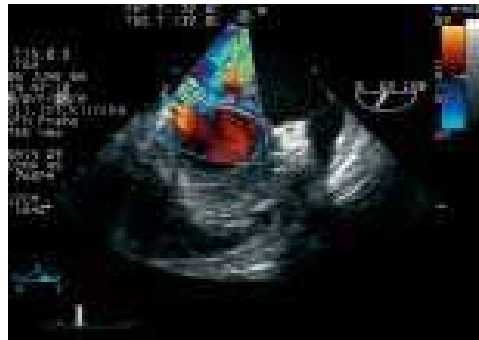

Obr. 3 TEE, dvoudutinová projekce se zobrazením ouška levé sínẽ; barevné dopplerovské mapován zachycuje tẽžkou doprovodnou mitrální regurgitaci

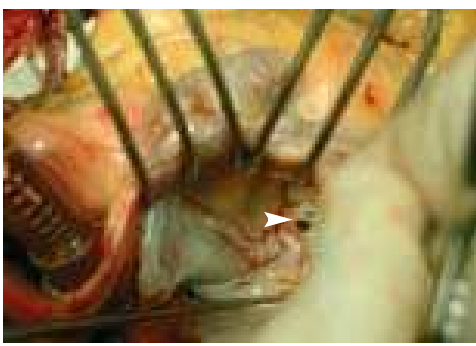

Obr. 4 Peroperační nález; pohled $z$ levé síně; jasně jsou patrné dva perforační otvory v zadním cípu mitrální chlopně př̀ posteromediální komisuře (označeno šipkou)

chorobami pojivové tkáně, jako je napr. Marfanův syndrom. Sekundární PMCH je podmíněn zmenšením dutiny leve komory, dysfunkcí papilárních svalů $\mathrm{u}$ ischemické choroby, rupturou šlašinky. Jako zánětlivý sekundární $\mathrm{PMCH}$ je označován prolaps

u revmatické choroby srdeční. Prolaps v důsledku postižení IE je vzácný. V literatuře je tato situace obvykle popsána formou kasuistických sdělení. Nomenklatura není jednotná. Jsou použivány terminy pozánětlivý prolaps, komisurálni prolaps nebo termín aneuryzma cípu mitrální chlopně.

\section{LITERATURA}

1. Aubert S, Barreda T, Acar C, et al. Mitral valve repair for commissural prolaps: surgical techniques and long term results. Eur J Cardiothorac Surg 2005;28:443.

2. Korber T, Petzsch M, Pulva K, et al. Perforated mitral valve aneurysma as a rare course of bacterial endokarditis. Z Kardiol 2001;90:867.

Jiři Král, Eva Kábrtová, Vilém Rohn*

III. interní klinika, *II. chirurgická klinika kardiovaskulární chirurgie, Všeobecná fakultní nemocnice a 1. lékařská fakulta Univerzity Karlovy, Praha, Česká republika

Adresa: doc. MUDr. Jiří Král, CSc., III. interní klinika VFN a 1. LF UK, U nemocnice 1, 128 08, Praha 2, Česká republika, e-mail: jiri.kral@vfn.cz 